\title{
The Effects of Animation Technique on the 7th Grade Science and Technology Course
}

\author{
Gokhan Aksoy \\ Ministry of National Education, IMKB Primary School, Erzurum, Turkey \\ Email: gokhanaksoy44@hotmail.com \\ Received May $5^{\text {th }}, 2012$; revised June $1^{\text {st }}, 2012$; accepted June $15^{\text {th }}, 2012$
}

\begin{abstract}
The purpose of this study is to determine the effect of animation technique on academic achievement of students in the "Human and Environment" unit lectured as part of the Science and Technology course of the seventh grade in primary education. The sample of the study consists of 58 students attending to the 7th grade of Erzurum MEB Yildizkent IMKB primary school under two different classes during the 20112012 academic year. While the lectures in the class designated as the animation group were given with animation technique, in the class designated as the control group Powerpoint presentations was utilized along with the traditional teaching methods. According to the findings, it was determined that animation technique is more effective than traditional teaching methods in terms of enhancing students' achievement. It was also determined in the study that, the Powerpoint presentations used together with the traditional teaching methods provided to the control group significantly help the students to increase their academic achievement.
\end{abstract}

Keywords: Human and Environment; Animation Technique; Simulation; Science and Technology; Academic Achievement

\section{Introduction}

\section{Animation Technique in Education}

Learning and teaching activities in the education and training process have an important role in presenting permanent information to students. In order to enable students to learn better, their advanced mental process skills have to be developed. In other words, the skills needed in order to create solution for problems and learn by comprehension instead of memorizing have to be given to students. Therefore an effective science education has to be provided in school. Accordingly, in science education teaching the skills for reaching information is much more important to providing the available information to students (Black, 2005; Karaçöp, 2010; Kim, Yoon, Whang, Tversky, \& Morrison, 2007; Wu \& Shah, 2004). In this context, there are various methods used in science education in order to enable the topics to be better comprehended. Both researchers and educational practitioners have believed that animation would facilitate learning. Because, animations are more realistic for showing change; they can demonstrate in action the systems to be taught and animations can show change in time, they are thought to be natural and effective for conveying change in time (Kim, Yoon, Whang, Tversky, \& Morrison 2007; Nielsen 1995). In technology-aided education, visual materials such as animations, animated pictures and multimedia software have a great importance (Aldağ \& Sezgin, 2002; Hall, 2012; Mayer \& Moreno, 2002). Use of animations has a significant effect in teaching the abstract topics of science and technology courses. Use of animations together with teaching methods and techniques and having the students actively participate to the process ensure the provision of an effective and efficient education. The developments experienced in information technologies brought the use of computer technologies in the learning- teaching environments into prominence. Developments in computer technologies make it possible for the educators to teach by using graphics, videos, simulations and animations together with written texts. Scientific thinking methods should be also presented in animations (Doymuş, Şimşek, \& Karaçöp, 2009; Karaçöp, 2010).

Animations are the most known kind of pictorial forms. Animation is the rapid display of a sequence of pictures on computer screen. Animations have three characteristics. These are the pictures, display of certain movements and simulation (Weiss, Knowlton, \& Morrison, 2002). Also salience and briskness have an important place in animations. Animations should correspond to the context of the topics, otherwise animations may become distracting and the intended objectives cannot be achieved with the use of animations. Briskness in animations reifies comprehension of abstract topics (Ploetzner, Lippitsch, Galmbacher, Heuer, \& Scherrer, 2009; Sweller, 2005; Tezcan \& Y1lmaz, 2003; Vermaat, Kramers-Pals, \& Schank, 2004).

\section{The Purpose of the Study}

The purpose of this study is to determine the effects of animation technique and the traditional teaching methods on the academic achievement of students receiving "human and environment" unit of the 7 th grade science and technology course.

\section{Model}

Within the scope of primary school 7 th grade science and technology lesson's "human and environment" unit, in this study, control group design of pretest - posttest was predicated to examine the results of two different teaching techniques on students' academic achievements (McMillan \& Schumacher, 
2006).

\section{Participants}

Sample of the study consist of 58 students of two classes of a primary school during the academic year of 2011-2012. One of the classes was assigned as the Animation Group (AG) $(n=28)$, another one was assigned as the Control Group (CG) $(n=30)$. The study was continued in all groups for three weeks.

\section{Data Collection Tools}

\section{Academic Achievement Test (AAT)}

Academic Achievement Test was designed taking into consideration the "human and environment" unit in the study and to be able to measure student attainments by making use of primary school 7 th grade science and technology program. AAT was designed as 25 questions multiple choice test following the preparation of questions specifications table which was prepared according to subject distribution and questions and examined and corrected by 3 academics who are leading experts on the science education and 3 science and technology teachers (teaching at 7 th grade). After these adjustments, AAT was applied on 48 8th grade students from 2 different classes, who had studied the subject previously and hence, the reliability of the test measurements were established. 5 questions in the AAT which were found to be dysfunctional were removed from the test. Thus, the AAT was prepared as 20 question test and its reliability coefficient was determined as 0.66 . AAT was applied both groups as pretest and posttest to determine the change in the academic achievement level.

\section{The Study}

\section{Teaching with Animation Technique}

The animations related to the "Human and Environment" unit were obtained from several websites. Distributions of these animations and simulations according to subjects in the "Human and Environment" unit, and the related website addresses are presented in Table 1. In addition to the animations, scientific game and movie were downloaded from the internet and utilized in the education of the students. Suitability of the animations to the contexts of the subjects were examined by a prelector engaged in the area of science education. The researcher provided the students with the basic information concerning the subjects of the "Human and Environment" unit along with the prepared animations. During the courses uncomprehended animations were played again and the courses were completed by making class discussions. Lecturing of the subjects included in the "Human and Environment" unit was completed in three weeks. In order to determine the level of increase in students' achievements at the end of the study, AAT posttest was used.

\section{Teaching with the Traditional Teaching Methods}

In the class designated as the control group, lecturing of the subjects included in the "Human and Environment" unit was realized according to the traditional teaching methods. In control group the lecture was given with the Powerpoint presentations prepared by the researcher. While the researcher performed the presentation, students listened and took notes. In
Table 1.

Subjects in the "Human and Environment" unit and the related animations used in these subjects.

\begin{tabular}{ll}
\hline \multicolumn{1}{c}{ Subjects } & \multicolumn{1}{c}{ Related animations } \\
\hline Energy transfers & URL1 \\
Food chain & URL2, URL3, URL4, URL5 \\
Natural disasters & URL6, URL7 \\
Ecosystem. & URL8, URL9, URL10, URL11, URL12 \\
Population & URL13, URL14, URL15, URL16 \\
Global warming & URL17, URL18, URL19 \\
Water cycle & URL20, URL21 \\
Acid rain & URL22, URL23, URL24 \\
Carbon cycle & URL25 \\
Ozone hole and ozone depletion & URL26, URL27 \\
Greenhouse effects & URL28, URL29, URL30, URL31 \\
Food web & URL32, URL33 \\
\hline
\end{tabular}

addition to these, while teaching some of the subjects; the students were divided into groups of five and asked to present the subjects as a group. Students continued their studies out of the class through textbooks and other sources provided by the researcher. During the lectures, students were asked questions at certain times and feedbacks were made according to their answers. Students were also given homework for studying the subjects out of the class. At the end of each lesson, the students were asked to read about the subjects of the next lesson and be prepared for it. In the control group, lecturing of the subjects included in the "Human and Environment" unit lasted for three weeks. Lectures in both animation and control groups were given by the researcher. In order to determine the level of increase in students' achievements at the end of the study, AAT posttest was used.

\section{Findings}

In this part, the findings obtained from examining the effects of the animation technique and the traditional teaching methods on the academic achievement levels of the students in the "Human and Environment" unit of the 7th grade science and technology course are presented.

The Academic Achievement Test (AAT) was implemented to the students included in both the animation and the control group individually once before the lectures as pre-test and once after the lectures as post-test. The data obtained from independent $t$ test analysis of the AAT pre-test and AAT post-test score averages are presented in Table 2.

Examining the $p$ values in Table 2 according to a significance level of 0.05 shows that there is no difference between the animation and control groups in terms of the AAT pre-test scores obtained $(p>0.05)$. According to these data it is possible to assert that the preknowledge on the subjects of the "Human and Environment" unit of the students in both groups were in the same level (Animation Group $=55.18$; Control Group $=$ 53.17). 
On the other hand, examining the $p$ values in Table 2 according to a significance level of 0.05 indicates the presence of a statistically significant difference between the animation and control groups in terms of the AAT post-test scores obtained ( $p$ $<0.05$ ). Examining the scores obtained from the AAT post-test implemented to both groups following the completion of the courses pointed out that a statistically significant difference between the two groups was established in terms of the students' academic achievement levels on the subjects of the "Human and Environment" unit (Animation Group = 78.61; Control Group $=63.17)$. With this, it was determined that the animation group was superior to the control group in increasing their academic achievements.

In order to determine the level with which the groups increased their academic achievement levels by examining the pre-test and post-test results of each group separately, the data obtained from the matched group $t$ test analysis of the point averages obtained by both of the groups from the pre-test and post-test are presented in Table 3.

With the examination of the AAT pre-test and AAT post-test point average data presented in Table 3, it was determined that the animation technique applied to the animation group resulted in a significant difference in terms of increasing students' academic achievements concerning the subjects included in the "Human and Environment" unit. It was also determined from considering the AAT pre-test and AAT post-test point averages presented in Table 3 that, also the traditional teaching methods applied to the control group caused a statistically significant difference in terms of increasing students' academic achievements in the "Human and Environment" unit. However, with the examination of the $p$ values, it was determined that the animation group increased its academic achievements in a much greater level than the control group.

\section{Conclusion}

In this part the findings of the study were interpreted and discussed, and also some suggestions that may set light to the future studies concerning the techniques and methods used in this study were made. The teaching techniques, methods and tests used in the 7th grade "Human and Environment" unit are presented below.
With the examination of the data obtained from applying the AAT pre-test to both animation and control groups, it was determined that the achievement levels of both of the groups were above $53 \%$, and that there was no significant difference in the preknowledge of the students of the two groups concerning the subjects of the "Human and Environment" unit (Table 2). It is believed that the absence of a significant difference between the preknowledge of the animation and control group was due to the fact that the students of both groups received the same education curriculum in the past. Also, high levels of preknowledge in science and technology courses facilitate teaching, comprehension of related activities and subjects, and creation of solutions to the problems that may be experienced. It is also observed from other studies that the preknowledge of students that received the same education curriculum are on the same level (Aksoy \& Doymuş, 2011; Doymus, 2007; Doymuş, Şimşek, \& Karaçöp, 2009).

According to the findings obtained from the statistical analysis of the AAT post-test scores of the two groups, it was determined that a statistically significant difference was created in terms of increasing the groups' academic achievements in the related subjects, in consequence of the implementation of the animation technique and the traditional teaching methods in teaching the subjects included in the "Human and Environment" unit of the 7th grade science and technology course. The animation group was found out to be more successful than the control group in terms of the AAT post-test points (Table 2). Provision of additional information provided together with the related animations can be interpreted among the reasons why the students, on whom the animation technique was implemented, attained higher academic achievement levels than the students of the control group.

The consideration that utilization of animations in this way as part of education is effective in teaching scientific facts, phenomena, experiments and concepts were also set forth in other studies (Schank \& Kozma, 2002). The findings of this study indicating that animation technique enables higher academic achievement in comparison to traditional teaching methods is in line with the results of the previously conducted studies (Frailich, Kesner, \& Hofstein, 2009; Özmen, 2008; ÖztürkÜrek \& Tarhan, 2005; Sanger, Brecheisen, \& Hynek, 2001; Talib, Matthews, \& Secombe, 2005; Yang, Andre, \& Greenbowe,

Table 2.

Independent sample $t$ test analysis of the point averages scored from AAT pre-test and AAT post-tests values.

\begin{tabular}{ccccccc}
\hline \multirow{2}{*}{ Tests } & \multicolumn{2}{c}{ Animation group } & \multicolumn{2}{c}{ Control group } & \multirow{2}{*}{$t$} & \multirow{2}{*}{ ( } \\
\cline { 2 - 5 } & $\mathrm{X}$ & $\mathrm{SD}$ & $\mathrm{X}$ & $\mathrm{SD}$ & & \\
\hline AAT pre-test & 55.18 & 7.99 & 53.17 & 7.13 & 1.01 & 0.31 \\
AAT post-test & 78.61 & 9.24 & 63.17 & 13.98 & 4.92 & 0.01 \\
\hline
\end{tabular}

Table 3.

Paired sample $t$ test analysis of the AAT pre-test and AAT post-test point averages of both groups.

\begin{tabular}{ccccccc}
\hline \multirow{2}{*}{ Groups } & \multicolumn{2}{c}{ AAT pre-test } & \multicolumn{2}{c}{ AAT post-test } & \multirow{2}{*}{$t$} & \\
\cline { 2 - 5 } & $\mathrm{X}$ & $\mathrm{SD}$ & $\mathrm{X}$ & $\mathrm{SD}$ & & \\
\hline Animation group & 55.18 & 7.99 & 78.61 & 9.24 & 10.29 & 0.01 \\
Control group & 53.17 & 7.13 & 63.17 & 13.98 & 3.42 & 0.01 \\
\hline
\end{tabular}


2003). The questions asked by the researcher in order to reveal students' preknowledge on the subjects, answering the questions concerning the subjects and the contents of the animations, class discussions held after the presentation of the animations and repetition of the uncomprehended subjects, in addition to the provision of the animations and simulations are among the other reasons of how the students of the animation group was more successful than the students of the control group. The finding that the use animation technique brings along a considerable difference in students' achievements is in line with the results of the previously conducted studies (Kelly \& Jones, 2007; Rotbain, Marbach-Ad, \& Stavy, 2008).

It was determined that, after completion of the teaching activities both of the groups increased their academic achievement levels on the subjects included in the scope of the study in terms of their AAT pre-test and AAT post-test point averages (Table 3). The $p$ values provided in the table for the 7 th grade science and technology course, "Human and Environment" unit, indicate that the educative process were useful at high levels for both of the groups. The Powerpoint presentations made in relation with the subject during the implementation of the traditional teaching methods can be shown as the reason how both of the groups benefited from the process at such high levels. The researcher's utilization of Powerpoint during the course enabled a planned and successive presentation of the subject, drawing the students' attention to the subjects, enhancing students' levels of perception, teaching the lesson more efficiently and presentation of different information (Hakverdi-Can \& Dana, 2012; Para \& Reis, 2009).

The techniques and methods that facilitate teaching the difficult subjects in science courses are frequently utilized in education environments. In this study, animation technique and the traditional teaching methods supported by PowerPoint presentations were used in order to facilitate teaching and learning of the subjects included in the "Human and Environment" unit. In order to obtain more effective and efficient results from the studies that will be conducted in the future with the animation technique, particular attention should be paid for ensuring that the animations are not distracting, suitable to the levels of the students and easily accessible by the students. It is my belief that, in future studies formation of data warehouses from where animations and simulations can be readily applied to the subjects to be taught by the researchers will affect education activities positively and that it will be useful to repeat the concept of this present study on the social sciences course at primary education level and on physics, biology, astronomy and geography courses at middle school and high school levels.

\section{REFERENCES}

Aksoy, G., \& Doymuş, K. (2011). Effects of cooperative reading-writingapplication technique in application in science and technology course. Gazi University Journal of Gazi Educational Faculty, 31, 43-59.

Aldağ, H., \& Sezgin, M. E. (2002). Dual coding theory in multimedia applications. Marmara Universitesi Ataturk Egitim Fakultesi Egitim Bilimleri Dergisi, 15, 29-44.

Black, A. A. (2005). Spatial ability and earth science conceptual understanding. Journal of Geoscience Education, 53, 402-414.

Doymus, K. (2007). Effects of a cooperative learning strategy on teaching and learning phases of matter and one-component phase diagrams. Journal of Chemical Education, 84, 1857-1860. doi:10.1021/ed084p1857

Doymuş, K., Şimşek, Ü., \& Karaçöp, A. (2009). The effects of compu- ter animations and cooperative learning methods in micro, macro and symbolic level learning of states of matter. Eurasian Journal of Educational Research, 36, 109-128.

Frailich, M., Kesner, M., \& Hofstein, A. (2009). Enhancing students' understanding of the concept of chemical bonding by using activities provided on an interactive website. Journal of Research in Science Teaching, 46, 289-310. doi:10.1002/tea.20278

Hakverdi-Can, M., \& Dana, T. M. (2012). Exemplary science teachers' use of technology. The Turkish Online Journal of Technology, 11, 94-112.

Hall, T. (2012). Digital renaissance: The creative potential of narrative technology in education. Creative Education, 3, 96-100. doi: $10.4236 /$ ce. 2012.31016

Karaçöp, A. (2010). Effects of jigsaw and animation tecniques on students' understanding of subjects on electrochemistry and chemical bonding units. Erzurum: Ataturk University.

Kelly, R. M., \& Jones, L. L. (2007). Exploring how different features of animations of sodium chloride dissolution affect students' explanations. Journal of Science Education and Technology, 16, 413-429. doi:10.1007/s10956-007-9065-3

Kim, S., Yoon, M., Whang, S. M., Tversky, B., \& Morrison, J. B. (2007). The effect of animation on comprehension and interest. Journal of Computer Assisted Learning, 23, 260-270. doi:10.1111/j.1365-2729.2006.00219.x

Mayer, R. E., \& Moreno, R. (2002). Aids to computer-based multimedia learning. Learning and Instruction, 12, 107-119. doi:10.1016/S0959-4752(01)00018-4

McMillan, J. H., \& Schumacher, S. (2006). Research in education: Evidence-based inquiry (6th ed.). Boston, MA: Allyn and Bacon.

Nielsen, J. (1995). Guidelines for multimedia on the web. URL (last checked 1 October 2004). http://www.useit.com/alertbox/9512.html

Özmen, H. (2008). The influence of computer-assisted instruction on students' conceptual understanding of chemical bonding and attitude toward chemistry: A case for Turkey. Computers \& Education, 51, 423-438. doi:10.1016/j.compedu.2007.06.002

Öztürk-Ürek, R., \& Tarhan, L. (2005). An active learning application based on constructivism to remedy misconceptions on "covalent bonding". Hacettepe University Journal of Education, 28, 168-177.

Para, D., \& Reis, Z. A. (2009). Egitimde bilisim teknolojileri kullanilmasi: Kimyada su dongusu. 6th. Akademik Bilisim Konferansi Bildirileri, Sanliurfa, 11-13 February 2009.

Ploetzner, R., Lippitsch, S., Galmbacher, M., Heuer, D., \& Scherrer, S. (2009). Students' difficulties in learning from dynamic visualizations and how they may be overcome. Computers in Human Behavior, 25, 56-65. doi:10.1016/j.chb.2008.06.006

Rotbain, Y., Marbach-Ad, G., \& Stavy, R. (2008). Using a computer animation to teach high school molecular biology. Journal of Science Education and Technology, 17, 49-58. doi:10.1007/s10956-007-9080-4

Sanger, M. J., Brecheisen, D. M., \& Hynek, B. M. (2001). Can computer animations affect college biology students' conceptions about diffusion \& osmosis? The American Biology Teacher, 63, 104-109. doi:10.1662/0002-7685(2001)063[0104:CCAACB]2.0.CO;2

Schank, P., \& Kozma, R. (2002). Learning chemistry through the use of a representation-based knowledge building environment. Journal of Computers in Mathematics and Science Teaching, 21, 253-279.

Sweller, J. (2005). Implications of cognitive load theory for multimedia learning. In R. E. Mayer (Ed.), The Cambridge handbook of multimedia learning (pp. 19-30). Cambridge, MA: Cambridge University Press.

Talib, O., Matthews, R., \& Secombe, M. (2005). Computer-animated instructions and students conceptual chance in electrochemistry: Preliminary qualitative analysis. International Education Journal, 5, 2942.

Tezcan, H., \& Yılmaz, Ü. (2003). Success with the traditional teaching method of teaching chemistry, computer animations and effects of the conceptual. Pamukkale University Journal of Education, 14, 1832.

URL1 (last checked 8 January 2012).

http://www.kscience.co.uk/animations/energy_transfer.swf

URL2 (last checked 7 February 2012). 
http://msnucleus.org/membership/storybooks/foodchain.swf

URL3 (last checked 7 February 2012).

http://www.ecokids.ca/pub/eco_info/topics/frogs/chain_reaction/asse ts/flash/chain_reaction.swf

URL4 (last checked 9 February 2012).

http://teacher.scholastic.com/activities/explorer/ecosystems/be_an_e xplorer/map/line_experiment14.swf

URL5 (last checked 9 February 2012).

http://www.berghuis.co.nz/abiator/patana/6t/index/science/adapt/fc1. swf

URL6 (last checked 9 February 2012).

http://mrhardy.wikispaces.com/Natural+Disasters.swf

URL7 (last checked 7 February 2012).

http://www.sci.sdsu.edu/volcano/

URL8 (last checked 9 February 2012).

http://www.earthmatters4kids.org/EcoSystem.swf

URL9 (last checked 9 February 2012).

http://www.wetrocks.com/pdf/ecosystem.swf

URL10 (last checked 9 February 2012).

http://www.inspiredeconomies.com/intelligibleecosystems/Flash_Mo dels.htm

URL11 (last checked 9 February 2012).

http://www.wadsworthmedia.com/biology/0495119814_starr/big_pic ture/ch41_bp.swf

URL12 (last checked 9 February 2012).

http://atanesa.atauni.edu.tr/NesneGor.aspx?NesneId=7190

URL13 (last checked 8 January 2012).

http://atanesa.atauni.edu.tr/NesneGor.aspx?NesneId=7192

URL14 (last checked 8 January 2012).

http://www.poodwaddle.com/clocks/worldclock/

URL15 (last checked 7 January 2012).

http://cgz.e2bn.net/e2bn/leas/c99/schools/cgz/accounts/staff/rcham-

bers/GeoBytes/Content\%20Generator\%20Quizzes/Halfamin/Yr8Pop ulation/population.swf

URL16 (last checked 5 February 2012).

http://www.shambles.net/worldclock/worldclock.swf

URL17 (last checked 9 February 2012).

http://www.kidsnewsroom.org/climatechange/global_warming_versi on $2 . h$ tml

URL18 (last checked 9 February 2012).

http://library.thinkquest.org/28313/flash/globalwarming.htm

URL19 (last checked 6 January 2012).

http://www.fccj.info/gly1001/animations/Chapter20/GlobalWarming. html

URL20 (last checked 5 February 2012)

http://www.kidsnewsroom.org/climatechange/water_cycle_version2. html
URL21 (last checked 7 February 2012).

http://atanesa.atauni.edu.tr/NesneGor.aspx?NesneId=10503

URL22 (last checked 6 January 2012).

http://www.absorblearning.com/media/attachment.action?quick=vd\& att $=2248$

URL23 (last checked 9 February 2012).

http://www.epa.gov/acidrain/education/site_students/acidrain.swf

URL24 (last checked 9 February 2012).

http://www.ecokids.ca/pub/eco_info/topics/frogs/acid_rain/assets/fla sh/acid_lake_final3.swf

URL25 (last checked 8 January 2012).

http://www.kscience.co.uk/animations/carbon cycle.swf

URL26 (last checked 8 February 2012).

http://www.ehso.com/ehso2.php?URL=http $\% 3 \mathrm{~A} \% 2 \mathrm{~F} \% 2 \mathrm{Fjwocky} . g s f$ c.nasa.gov/multi/multi.html

URL27 (last checked 8 January 2012).

http://glencoe.mcgrawhill.com/sites/dl/free/0078695104/383927/Vis _Global_Effects.swf

URLL28 (last checked 8 February 2012).

http://www.damocleseu.org/education/Animation_about_the_greenh ouse effect 182. shtml

URL29 (last checked 18 January 2012).

http://prof.danglais.pagespersoorange.fr/animations/environment/gre enhouse/greenhouse.htm

URL30 (last checked 8 January 2012).

http://www.keesfloor.nl/lezingen/greenhouse.swf

URL31 (last checked 15 January 2012).

http://sunshine.chpc.utah.edu/labs/atmosphere/greenhouse.swf

URL32 (last checked 8 January 2012).

http://ecomuve.gse.harvard.edu/foodweb/Food\%20Web.swf

URL33 (last checked 8 January 2012).

http://www.ecokids.ca/pub/eco_info/topics/frogs/chain_reaction/asse ts/flash/chain_reaction.swf

Vermaat, H., Kramers-Pals, H., \& Schank, P. (2004). The use of animations in chemical education. Proceedings of the International Convention of the Association for Educational Communications and Technology, Anaheim, October 2003, 430-441.

Weiss, R. E., Knowlton, D. S., \& Morrison, G. R. (2002). Principles for using animation in computer based instruction: Theoretical heuristics for effective design. Computers in Human Behavior, 18, 465-477. doi:10.1016/S0747-5632(01)00049-8

Wu, H. K., \& Shah, P. (2004). Exploring visuospatial thinking in chemistry learning. Science Education, 88, 465-492. doi: $10.1002 /$ sce. 10126

Yang, E., Andre, T., \& Greenbowe, T. J. (2003). Spatial ability and the impact of visualization/animation on learning electrochemistry. International Journal of Science Education, 25, 329-349. 